\title{
Keragaan Penggunaan Lahan Eksisting di Hulu Sub DAS Cikapundung Berdasarkan Indeks Vegetasi dan Temperatur Permukaan Lahan
}

\author{
M. Amir Solihin* dan Noviani Putri \\ Departemen Ilmu Tanah dan Sumberdaya Lahan, Fakultas Pertanian, Universitas Padjadjaran \\ J1. Raya Bandung-Sumedang KM 21, Jatinangor, Indonesia 45363 \\ *Alamat korespondensi: m.amir.solihin@unpad.ac.id
}

\begin{abstract}
Land uses existing performance of the upstream of Cikapundung watershed based on vegetation indeks and land surface temperature
\end{abstract}

Land use performance is one of very important variable to support ecological function of upstream of Cikapundung watershed. The land use performance can be identified by vegetation index and land surface temperature that describes favourable environment for plants as well as soil and water conservations of a watershed. This study aimed to determine vegetation index and land surface temperature as indicators of land use performances in the upstream of the Cikapundung watershed. The study sites located in upstream of Cikapundung watershed in Lembang District. The vegetation index defined by Normalized Differences Vegetation Index (NDVI) that represented the level of greenness and density of vegetation. Land surface temperature defined by Mono Windows Algorithm (MWA) analysis. The results showed that the values of vegetation index and LST in upstream Cikapundung watershed were varied. The dominance of vegetation indices at lower value as well as the moderate to high LST were found on intensive upland agriculture. Vegetation index and LST of Cikapundung Watershed can be used as indicators of land uses performance to support ecological function monitoring of overall watershed condition.

Keywords: Cikapundung watershed, Land use, Landsat 8, Land surface temperature, Vegetation indeks

\begin{abstract}
ABSTRAK
Keragaan penggunaan lahan merupakan salah satu variabel yang sangat penting untuk mendukung fungsi ekologi bagian hulu DAS Cikapundung. Keragaan penggunaan lahan dapat diidentifikasi melalui nilai indeks vegetasi dan suhu permukaan lahan yang menggambarkan lingkungan yang menguntungkan bagi tanaman dan juga bagi konservasi tanah dan air di suatu DAS. Penelitian ini bertujuan untuk mengetahui indeks vegetasi dan suhu permukaan tanah sebagai indikator keragaan penggunaan lahan di bagian hulu DAS Cikapundung. Lokasi penelitian berada di bagian hulu DAS Cikapundung di Kabupaten Lembang. Indeks vegetasi ditentukan berdasarkan Normalized Differences Vegetation Indeks (NDVI) yang merepresentasikan tingkat kehijauan vegetasi. Suhu permukaan lahan ditentukan berdasarkan analisis Mono Windows Algortihm (MWA). Hasil analisis menunjukkan bahwa indeks vegetasi dan LST di DAS Cikapundung hulu bervariasi. Dominasi nilai indeks vegetasi yang rendah dan LST yang sedang hingga tinggi ditemukan pada pertanian tegalan intensif. Indeks vegetasi dan LST di DAS Cikapundung dapat digunakan sebagai indikator keragaan penggunaan lahan dalam memantau dukungannya terhadap peran fungsi ekologis kondisi DAS secara keseluruhan.
\end{abstract}

Kata Kunci: DAS cikapundung, Indeks vegetasi, Landsat 8, Penggunaan lahan, Suhu permukaan lahan 


\section{PENDAHULUAN}

Daerah Aliran Sungai (DAS) Citarum merupakan salah satu DAS terbesar di Indonesia yang mengalami permasalahan seiring dengan perkembangan wilayah yang pesat, terutama di kawasan hulu DAS. Hulu DAS Citarum berada di wilayah Cekungan Bandung dan juga sebagai bagian dari kawasan perkembangan wilayah Bandung Raya. Secara umum permasalahan yang terjadi di hulu DAS Citarum adalah pesatnya perubahan penggunaan lahan dengan tutupan lahan yang tinggi seperti hutan, perkebunan dan pertanian tanaman tahunan menjadi kawasan permukiman, pertanian semusim, peternakan dan industri. Hal ini selaras dengan hasil penelitian Salim dkk. (2019) menunjukkan adanya perubahan tutupan lahan di Hulu DAS Citarum berdampak pada 58\% air hujan yang jatuh menjadi aliran permukaan. Hal ini tentunya berdampak pada menurunnya daya dukung lahan bagi fungsi ekologis hulu DAS.

Salah satu bagian dari DAS Citarum yang banyak mengalami perubahan penggunaan lahan adalah Sub DAS Cikapundung bagian Hulu. Hulu sub DAS Cikapundung diantaranya berada di Kecamatan Lembang, Kabupaten Bandung Barat yang mempunyai fungsi ekologis bagi Cekungan Bandung. Rismana dan Firmansyah (2011) mengungkapkan bahwa perubahan lahan di Sub DAS Cikapundung Hulu dari tahun 2004 ke tahun 2009 seluas 7.125, 15 ha atau $57,62 \%$ dari luas total Sub DAS.

Perubahan penggunaan lahan di hulu Sub DAS Cikapundung yang terletak di Kecamatan Lembang tersebut dapat berdampak pada penurunan kemampuan lahan untuk menyerap air (Nurrochman, 2018). Perubahan tutupan lahan hutan ke penggunaan non hutan atau vegetasi tutupan rapat memengaruhi pola hidrologis dalam DAS secara menyeluruh (Salim dkk., 2019). Untuk itu, menurut Latuamury dkk. (2012), kerapatan tutupan vegetasi dapat memengaruhi hasil aliran air ke hilir DAS dan perlu diperhitungkan dalam pengelolaan DAS.

Identifikasi kerapatan vegetasi dapat digunakan untuk memantau perubahan penggunaan lahan di Hulu Sub DAS Cikapundung. Perubahan penggunaan lahan dapat dianalisis menggunakan gambaran indeks vegetasi yang menggambarkan tingkat tutupan lahan berdasarkan tingkat kehijauan dan kerapatan vegetasinya. Setiap kelas penggunaan lahan memiliki karakteristik sebaran vegetasi berbeda yang ditunjukkan dengan nilai indeks vegetasi (Kinthada et al., 2014; Zhao et al., 2017; Hidayati dkk., 2018), ataupun berdasarkan sebaran kerapatan vegetasi (Latuamury dkk., 2012; Irawan \& Sirait, 2017).

Terdapat berbagai metode untuk mengetahui kondisi tutupan lahan bervegetasi di suatu wilayah diantaranya metode point centered quarter (Munawwaroh, 2016), line transect (Arista dkk., 2017), quadrat sampling (Pertiwi dkk., 2019), dan vegetation index (Latuamury dkk., 2012). Sudiana \& Diasmara (2008) mengungkapkan bahwa vegetasi akan menyerap cahaya merah oleh klorofil kemudian memantulkan cahaya inframerah dekat oleh jaringan mesofil. Indeks vegetasi merupakan rasio antara pantulan (refleksi) gelombang red (merah) dan near infrared (NIR). Lebih lanjut Sudiana \& Diasmara (2008) menyatakan indeks vegetasi pada daratan tanpa atau minim-vegetasi seperti perairan, pemukiman, tanah kosong/terbuka akan menunjukan nilai rasio yang rendah, sedangkan pada wilayah dengan vegetasi rapat menunjukkan nilai rasio yang sangat tinggi.

Beberapa penelitian menunjukan adanya berbagai macam indeks vegetasi (Tucker, 1979; Sudiana \& Diasmara, 2008; Frananda dkk., 2015; Lintang dkk., 2017). Masing-masing indeks akan menunjukkan nilai yang bervariasi tergantung pada algoritma transformasi yang digunakan. Tucker (1979) dan Lintang dkk. (2017) mengungkapkan bahwa NDVI sebagai metode yang paling efisien dan matriks yang simpel dalam mengidentifikasi area bervegetasi yang berbeda.

Kondisi tutupan lahan juga erat kaitannya dengan keadaan suhu permukaan lahan atau land surface temperature (LST). LST merupakan suhu yang berada pada bagian terluar dari suatu objek karena adanya radiasi yang diserap oleh permukaan suatu benda. Semakin berkurang tutupan lahan vegetasi maka semakin tinggi suhu permukaan lahan, dan sebaliknya semakin rapat tutupan vegetasi maka semakin rendah suhu permukaan lahan (Arie, 2012).

Suhu permukaan lahan atau Land Surface Temperature (LST) adalah suhu bagian terluar dari suatu objek yang tergantung pada sifat fisik permukaan objek (Sutanto, 1994 dalam Utomo dkk., 2017). Secara umum, LST merupakan suhu pada permukaan tanah kosong atau suhu permukaan pada tanah yang tertutupi kanopi vegetasi dan suhu permukaan air pada tubuh air. Suhu permukaan suatu benda akan berbeda tergantung sifat fisik 
objek pada permukaan tersebut seperti: emisivitas, konduktivitas termal dan kapasitas panas jenis. Suhu permukaan akan menurun jika nilai emisivitas dan kapasitas panas jenis tinggi, sedangkan konduktivitas termal rendah (Utomo dkk., 2017).

Estimasi nilai LST mempertimbangkan faktor emisivitas vegetasi dan emisivitas tanah. Emisivitas adalah kemampuan suatu objek untuk memancarkan energi termal yang dimilikinya (Mallick et al., 2012). Suatu objek mampu memancarkan seluruh atau sebagian energinya karena semua benda dengan suhu di atas nol mutlak (0 Kelvin atau $-273,15^{\circ} \mathrm{C}$ ) memancarkan radiasi yang berada pada gelombang inframerah.

Variasi emisivitas di permukaan bumi sangat beragam dan dipengaruhi oleh variasi tutupan vegetasi, komposisinya, kelembaban, dan kekasaran permukaan. Emisivitas dinotasikan dengan epsilon (ع) dengan nilai antara 0 dan 1 menunjukkan suatu benda dengan emisivitas tinggi akan menyerap dan meradiasikan energi yang besar, sedangkan benda dengan emisivitas rendah akan menyerap dan meradiasikan energi lebih rendah (Sabin, 2007 dalam Fawzi, 2014). Emisivitas setiap objek didasarkan pada keseimbangan termal dalam Hukum Kirchhoff. Pemetaan emisivitas permukaan dengan data emisi termal citra akan mempermudah estimasi suhu permukaan bumi.

Perubahan suhu permukaan akan mempengaruhi cuaca dan pola iklim dunia (Ningrum \& Narulita, 2018). Kimuku \& Ngigi (2017) menyatakan LST dapat memberikan gambaran hubungan kondisi antara permukaan tanah dan atmosfer yang dipengaruhi oleh lingkungan interaksi manusia. Data LST berasal dari band TIR (Thermal Infrared) pada citra satelit. Metode yang digunakan untuk menentukan suhu permukaan adalah dengan algoritma seperti Split Window Algorithm (SWA), Dual Angel Algorithm (DAA), Single Channel Algorithm (SCA) (JiménezMuñoz and Sobrino, 2003), dan Mono Window Algorithm (MWA) (Qin \& Karnieli, 2001). Masingmasing algoritma tersebut memiliki fungsi dan tujuan tersendiri.

Perhitungan LST membutuhkan nilai brightness temperature dan nilai Land Surface Emissivity (LSE) sehingga didapat estimasi LST yang akurat. Nilai emisivitas dapat dihitung menggunakan beberapa persamaan diantaranya emisivitas dengan pendekatan Valor \& Caselles (1996) dan Sobrino et al. (2008). Hasil penelitian Sekertekin \& Bonafoni (2020) menyebutkan model LSE Sobrino et al. (2008) menghasikan nilai LST terbaik pada semua jenis Landsat dan metode LST, kemudian disebutkan juga metode LST dengan MWA dan model LSE Sobrino et al. (2008) akan menghasilkan nilai LST terbaik pada Landsat 8 dengan RMSE $2,52{ }^{\circ} \mathrm{K}$.

Identifikasi nilai indeks vegetasi dan LST dapat menggunakan citra satelit diantaranya NOAA AVHRR (Sandholt et al., 2002; Sudiana \& Diasmara, 2008), Terra MODIS (Sudiana \& Diasmara, 2008), WorldView (Hidayati dkk., 2018), dan Landsat 8 (Lintang dkk., 2017; Kurniawan dkk., 2017; Feng et al., 2019). Sumber citra yang paling mudah dan banyak digunakan untuk identifikasi permukaan lahan pada resolusi menengah salah satunya yaitu citra Landsat 8. Penelitian ini mengidentifikasi karakteristik indeks vegetasi dan LST pada berbagai penggunaan lahan di hulu sub DAS Cikapundung dengan menggunakan citra Landsat 8.

\section{BAHAN DAN METODE}

Lokasi penelitian berada di Kecamatan Lembang yang termasuk wilayah Hulu Sub DAS Cikapundung. Kegiatan pengolahan data dilakukan di Studio Survey Pemetaan dan Evaluasi Lahan, Departemen Ilmu Tanah dan Sumberdaya Lahan, Fakultas Pertanian Universitas Padjadjaran, Kecamatan Jatinangor, Kabupaten Sumedang, Provinsi Jawa Barat. Bahan yang digunakan diantaranya, Citra Landsat 8 perekaman 22 Mei 2019 dengan pertimbangan kondisi ketersediaan data citra yang paling baik untuk analisis data. Selain itu digunakan juga Peta Rupa Bumi Indonesia Kabupaten Bandung Barat 1: 25.000 dan image Google Earth.

\section{Pra Pengolahan Citra}

Pada tahapan pra pengolahan citra dilakukan koreksi geometri dan koreksi radiometrik menggunakan ERDAS. Nilai RMSE yang dianjurkan pada koreksi geometrik yaitu <0,5 (Jaya, 2010). Koreksi radiometrik menggunakan metode histogram equalization.

Tutupan awan yang terdapat di lokasi studi diidentifikasi melalui cloud masking pada ER mapper. Metode ini memanfaatkan band 9 (Cirrus) melalui tool highlight cloud sehingga awan menjadi kelas tersendiri. Selanjutnya dilakukan ISOCLASS Unsupervised Classification untuk mengklasifikasikan awan dan non-awan. Identifikasi bayangan dari efek awan dilakukan secara manual dengan delinasi area bayangan awan. Awan dan 
bayangan di lokasi studi tidak termasuk ke dalam area yang dianalisis karena respon objek yang tertangkap citra satelit tidak menampilkan pantulan ataupun emisi objek yang sebenarnya.

Citra yang diperoleh dari situs USGS tersedia dalam satu scene image dengan luas area 170 x 183 $\mathrm{km}$. Untuk mempermudah analisis dilakukan pemotongan citra disesuaikan dengan batasan administrasi lokasi studi. Pemotongan citra dilakukan dengan tool extract by mask pada ArcGIS.

Pemilihan kombinasi band dalam penelitian ini menjadi pertimbangan untuk dapat menampakan data yang dibutuhkan. Citra Landsat 8 mmemiliki band 4 (red), 5 (NIR), dan band 10-11 (TIRS) untuk pengolahan NDVI dan LST. Untuk pembaruan peta penggunaan lahan di Kecamatan Lembang digunakan band 4 (red), 3 (green) dan 2 (blue). Penajaman citra dilakukan untuk memperjelas objek dengan band 8 (panchromatic) dengan menggunakan aplikasi ERMapper.

\section{Analisis Penggunaan Lahan}

Peta penggunaan lahan yang digunakan berasal dari peta RBI (2016) dan diperbarui dengan citra Landsat 8 pada tanggal 22 mei 2019. Hal ini dimaksudkan agar perubahan yang terjadi pada waktu perekaman citra penelitian dapat disesuaikan dengan perkembangan terkini. Klasifikasi penggunaan lahan berdasarkan klasifikasi penggunaan lahan pada Peta Rupa Bumi Skala 1:50.000 (BSN, 2010) yaitu hutan, perkebunan/kebun, ladang/tegalan, sawah, sawah tadah hujan, semak belukar, tanah terbuka, dan lahan terbangun/permukiman.

\section{Analisis Land Surface Temperature (LST)}

Data persebaran Land Surface Temperature (LST) atau suhu permukaan lahan didapat dari hasil pengolahan band termal (band 10 dan 11) pada Citra Landsat 8. Pada pengolahan Citra Landsat 8, pendekatan metode LST yang digunakan yaitu dengan algoritma Mono Window Algorithm (MWA) pada masing masing band 10 dan 11, kemudian didapat LST rerata dari kedua band tersebut.

\section{Pengolahan Data Citra}

Pengolahan data citra dalam penelitian ini dilakukan untuk mendapatkan dua data yaitu indeks vegetasi dan LST. Tahapan pengolahan data diuraikan di bawah ini.

\section{1) Tahapan Pengolahan Indeks Vegetasi}

Pada citra Landsat 8, transformasi indeks vegetasi menggunakan band red (merah) dan band NIR (inframerah dekat) yang didasarkan pada nilai pantulan tertinggi (Lintang dkk., 2017). Nilai NDVI yang telah didapat selanjutnya diklasifikasikan menjadi beberapa kelas kehijauan (Tabel 1). Semakin besar nilai NDVI menggambarkan tingkat kehijauan vegetasi semakin tinggi.

Tabel 1. Klasifikasi tingkat kehijauan

\begin{tabular}{ccl}
\hline Kelas & Nilai NDVI & \multicolumn{1}{c}{ Keterangan } \\
\hline 1 & $(-1)-(-0,03)$ & Lahan tidak bervegetasi \\
2 & $(-0,03)-0,15$ & Kehijauan sangat rendah \\
3 & $0,15-0,25$ & Kehijauan rendah \\
4 & $0,25-0,35$ & Kehijauan sedang \\
5 & $0,36-1,00$ & Kehijauan tinggi
\end{tabular}

Sumber: Peraturan Menteri Kehutanan Republik Indonesia (2012)

2) Tahapan Pengolahan LST

Perkiraan LST di Kecamatan Lembang dapat dihitung dengan algorima LST berikut:

$L S T=\frac{B T}{1+\lambda *\left(\frac{B T}{P}\right) * \operatorname{In}(e)}$.

Keterangan :

LST: Land Surface Termperature atau suhu permukaan lahan

BT10-11: nilai brightness temperature band 10 dan band 11

$\lambda$ : Panjang gelombang dari radiasi yang diemisi

e: Emisivitas

P: $14380 \mathrm{mK}$ (h: konstanta Planck-6,626*10-34 Js; c: kecepatan cahaya-2,998*10 $\mathrm{m} / \mathrm{s} ; \square$ : konstanta Boltzman-1.38*10-23 J/K)

LST dihitung dengan Mono Window Algorithm (MWA) yang menggunakan koreksi emisivitas dengan memanfaatkan inversi dari persamaan Hukum Planck dan Boltzman. Perhitungan yang dilakukan sebagai berikut:

1. Perhitungan TOA Spectral Radiance Formula perhitungan TOA Spectral Radiance (USGS, 2019)

$L_{\lambda}=M_{L} Q_{c a l}+A_{L \text {. }}$

Keterangan:

$L$ : TOA spectral radiance (Watts $/\left(\mathrm{m}^{2 *} \mathrm{srad}^{*} \mu \mathrm{m}\right)$

$M_{L}$ : Band-specific multiplicative rescaling factor from the metadata

(RADIANCE_MULT_BAND_x, where $\mathrm{x}$ is the band number) 


\section{Qcal. Quantized and calibrated standard product pixel values $(\mathrm{DN})$}

$A_{L}$ : Band-specific additive rescaling factor from the metadata (RADIANCE_ADD_BAND_x, where $\mathrm{x}$ is the band number)

2. Perhitungan Brightness Temperature

Nilai spectral radiance band 10 dan band 11 yang diperoleh selanjutnya dikonversi menggunakan konstanta termal pada file metadata Landsat 8 menjadi suhu kecerahan (TB) menjadi $\mathrm{TB}_{10}$ dan TB11 (USGS, 2019).

$T B=\frac{K 2}{\operatorname{In}\left(\frac{K 1}{L \lambda}+1\right)}$.

Keterangan:

TB: At-satellite brightness temperature $(\mathrm{K})$

$L$ : TOA spectral radiance (Watts $/\left(\mathrm{m}^{2 *} \mathrm{srad}^{*} \mu \mathrm{m}\right)$

$\mathrm{K}_{1}$ : Konstanta kalibrasi dalam $\mathrm{W} /\left(\mathrm{m}^{2 *} \operatorname{srad}^{*} \mu \mathrm{m}\right)$ atau Band-specific thermal conversion constant from the metadata (K1_CONSTANT_BAND_x, where $\mathrm{x}$ is the band number)

$\mathrm{K}_{2}$ : Konstanta kalibrasi dalam Kelvin atau Bandspecific thermal conversion constant from the metadata (K2_CONSTANT_BAND_x, where $x$ is the band number)

Tabel 2. Nilai radian dan konstanta termal band pada Landsat 8

\begin{tabular}{lll}
\hline \multicolumn{1}{c}{ Keterangan } & \multicolumn{1}{c}{ Band 10} & \multicolumn{1}{c}{ Band 11} \\
\hline$M_{L}$ & 0,000342 & 0,000342 \\
$A_{L}$ & 0,1 & 0,1 \\
K1 & 1321,08 & 1201,14 \\
K2 & 777,89 & 480.89 \\
\hline
\end{tabular}

3. Perhitungan Normalized Difference Vegetation Index (NDVI)

Nilai NDVI menunjukan tingkat kerapatan vegetasi pada suatu area. Pada citra Landsat 8 kombinasi band yang digunakan dalam formula adalah band 4 (merah) dan band 5 (inframerah dekat). Rumus perhitungan NDVI pada Landsat 8 sebagai berikut:

$$
\mathrm{NDVI}=\frac{\mathrm{NIR}-\mathrm{Red}}{\mathrm{NIR}+\mathrm{Red}}
$$

4. Perhitungan Proportion of Vegetation (PV)

Nilai PV bertujuan untuk mengestimasi besaran fraksi pada suatu area yang tertutup vegetasi. Estimasi nilai PV didapat dari nilai NDVI yang didapat sebelumnya serta nilai NDVI (Soil atau minimum) dan NDVI (Vegetation atau maximum) yang diklasifikasikan dari nilai NDVI dengan ERDAS IMAGINE (Latif, 2014).

$\mathrm{PV}=\left[\frac{\text { NDVI-NDVImin }}{\text { NDVImax }- \text { NDVImin }}\right]^{2}$.

Keterangan:

PV: Proportion of Vegetation

NDVI: Nilai NDVI yang sebelumnya diperoleh

NDVI (Soil): Nilai NDVI untuk tanah $(=0,2)$

NDVI (Vegetation): Nilai NDVI untuk vegetasi (nilai terbesar NDVI)

5. Perhitungan Emissivity(E)

Emisivitas bertujuan untuk mengukur karakteristik yang melekat pada permukaan bumi dan mengukur kemampuannya unruk mengubah energi termal atau panas menjadi energi radiasi. Perhitungan E menggunakan nilai PV dalam persamaan Sobrino et al. (2008).

$e=0,004 P V+0,986$

Keterangan

e: Emisivitas

6. Perhitungan Rerata LST Band 10 dan Band 11 Nilai LST band 10 dan band 11 dihitung mendapatkan nilai LST rerata sehingga dapat merepresentasikan nilai LST aktual di lapangan.

LSTrerata $=\frac{\text { LST 10+LST 11 } \ldots \ldots . .(7)}{2}$

Keterangan:

LST 10 : Nilai LST band 10 yang sebelumnya telah diperoleh

LST 11 : Nilai LST band 11 yang sebelumnya telah diperoleh

\section{Analisis Statistik}

Analisis standar deviasi menunjukkan keragaman atau variasi pada suatu data. Semakin besar nilai standar deviasi maka keragaman data tinggi. Standar deviasi dapat dihitung dengan rumus berikut (Soewarno, 1995):

$$
S_{x}=\sqrt{\frac{\sum_{i=1}^{n}\left(x_{i}-\bar{x}\right)^{2}}{n-1}} .
$$




\section{HASIL DAN PEMBAHASAN}

\section{Penggunaan Lahan}

Peta penggunaan lahan RBI yang telah diperbarui dengan citra Landsat 8 (Gambar 1) digunakan untuk melihat karakteristik nilai NDVI pada berbagai penggunaan lahan di lokasi studi. Penggunaan lahan tegalan yang terluas di Hulu Sub DAS Cikapundung menunjukkan dominasi penggunaan lahan kering yang intensif di lokasi studi (Tabel 3).

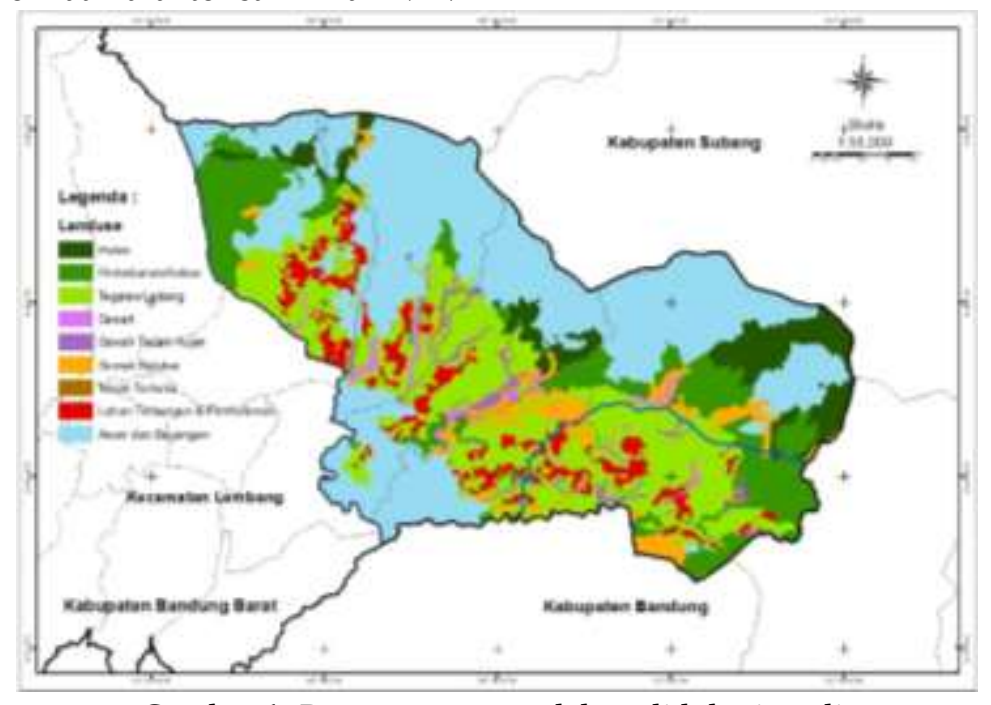

Gambar 1. Peta penggunaan lahan di lokasi studi.

Tabel 3. Luasan penggunaaan lahan di lokasi studi

\begin{tabular}{clcc}
\hline No. & Jenis Guna Lahan & $\begin{array}{c}\text { Luasan } \\
\left(\mathrm{km}^{2}\right)\end{array}$ & \% Luas \\
\hline 1. & Kawasan Hutan & 3,06 & 11,34 \\
2. & Kebun-Perkebunan & 6,38 & 23,66 \\
3. & Tegalan-Ladang & 11,63 & 43,10 \\
4. & Sawah (irigasi) & 0,74 & 2,74 \\
5. & Sawah (tadah hujan) & 0,84 & 3,10 \\
6. & Semak dan belukar & 2,11 & 7,84 \\
7. & Tanah kosong & 0,05 & 0,18 \\
8. & Lahan terbangun & 2,17 & 8,05 \\
\hline
\end{tabular}

\section{Persebaran NDVI}

Persebaran nilai NDVI di Kecamatan Lembang berkisar antara terendah $-0,228426$ dan tertinggi 0,461794 (Gambar 2). Nilai NDVI rendah direpresentasikan dengan warna kuning-merah, sedangkan NDVI tinggi berwarna hijau muda-hijau tua. Daratan non-vegetasi seperti lahan terbangun, tanah kosong, perairan dan wilayah dengan kondisi vegetasi rusak akan memiliki nilai rasio minimum, sedangkan wilayah dengan vegetasi yang rapat dan sangat rapat memiliki nilai rasio maksimum (Sudiana \& Diasmara, 2008).

Nilai NDVI dapat merepresentasikan tingkat kehijauan dan kerapatan tajuk vegetasi. Klasifikasi dilakukan berdasarkan Peraturan Menteri
Kehutanan No P.12/Menhut-II/2012. Tabel 4 menunjukkan luasan areal berdasarkan tingkat kehijauan dengan luasan terbesar ada pada kelas kehijauan sangat rendah (NDVI $(-0,03)-0,15)$, sedangkan luasan terendah pada kelas kehijauan tinggi (NDVI 0,36 - 1,00). Tingkat kehijauan rendah yang terluas pada penggunaan lahan pada tegalan/ladang. Tegalan didominasi tanaman hortikultura tanaman semusim yang memiliki tinggi tanaman dominan rendah dan jarak tanam kurang rapat sehingga masih terdapat tanah kosong diantara tanaman.

Penggunaan lahan hutan dan perkebunan memiliki tingkat kehijauan tinggi sampai rendah dan dominan pada kelas kehijauan rendah. Hal ini dikarenakan pada penggunaan lahan hutan di lokasi studi sebagian besar memiliki persebaran vegetasi yang beragam. Lahan perkebunan dan kebun memiliki variasi jenis vegetasi, jarak tanam, dan kondisi tajuk yang rendah sehingga rata-rata pada kelas kehijauan yang dominan rendah.

Lahan terbangun dan lahan tidak bervegetasi memiliki NDVI yang termasuk pada kelas kehijauan tingkat sangat rendah. Hal ini disebabkan oleh sedikitnya sebaran vegetasi dan tingginya emisivitas pada material bangunan sehingga memiliki indeks vegetasi lebih rendah dari pada lahan yang bervegetasi. 


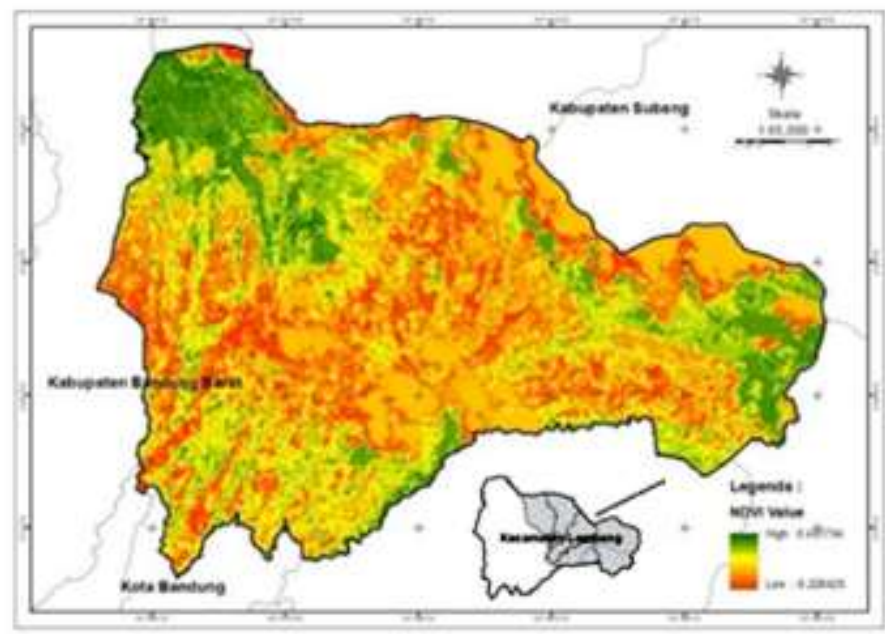

Gambar 2. Persebaran nilai NDVI di lokasi studi di Kecamatan Lembang.

Tabel 4. Luasan area setiap kelas kehijauan NDVI

\begin{tabular}{clrr}
\hline No. & $\begin{array}{c}\text { Klasifikasi } \\
\text { Kehijauan NDVI }\end{array}$ & $\begin{array}{c}\text { Luasan } \\
\left(\mathrm{km}^{2}\right)\end{array}$ & \% Luas \\
\hline 1. & Tinggi & 0,24 & 0,89 \\
2. & Sedang & 2,80 & 10,46 \\
3. & Rendah & 5,07 & 18,88 \\
4. & Sangat rendah & 9,79 & 36,47 \\
5. & Lahan tanpa & 8,94 & 33,30 \\
& vegetasi & & \\
\hline
\end{tabular}

Berdasarkan pada keragaan indeks vegetasi pada Tabel 4, menunjukkan tingkat tutupan vegetasi di lokasi studi dominan rendah. Hal ini tentunya akan berpengaruh pada fungsi ekologis lokasi studi sebagai bagian dari area hulu Sub DAS Cikapundung yang berperan sebagai area tangkapan air. Apabila tingkat tutupan vegetasinya rendah, maka fungsi ekologis DAS kurang optimal. Hal ini selaras dengan hasil penelitian Salim dkk. (2019) bahwa penurunan tutupan lahan berdampak pada peningkatan aliran permukaan.

\section{Land Surface Temperature (LST)}

Penentuan LST di lokasi studi tergantung pada nilai emisivitas permukaan lahan. Emisivitas mendekati 1 atau 1 menunjukkan permukaan objek dapat menyerap radiasi sempurna dan memancarkan emisi yang tinggi (Sabin, 2007 dalam Fawzi, 2014). Pada Gambar 3A, terlihat di Kecamatan Lembang nilai emisivitas tertinggi 0,991616 dan nilai emisivitas terendah 0,986979 . Nilai emisivitas yang tinggi (atau semakin mendekati 1 umumnya terdapat pada penggunaan lahan hutan sedangkan emisivitas rendah berada di permukiman. Nilai emisivitas didapat dari persamaan yang menggunakan nilai NDVI yang merepresentasikan kerapatan vegetasi. Hutan memiliki tingkat kerapatan vegetasi yang tinggi sehingga menunjukkan nilai emisivitas tinggi.

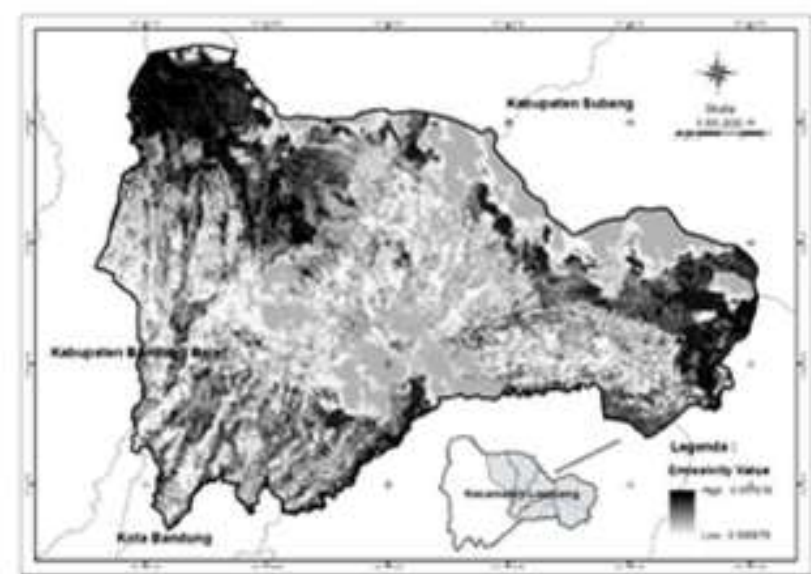

A

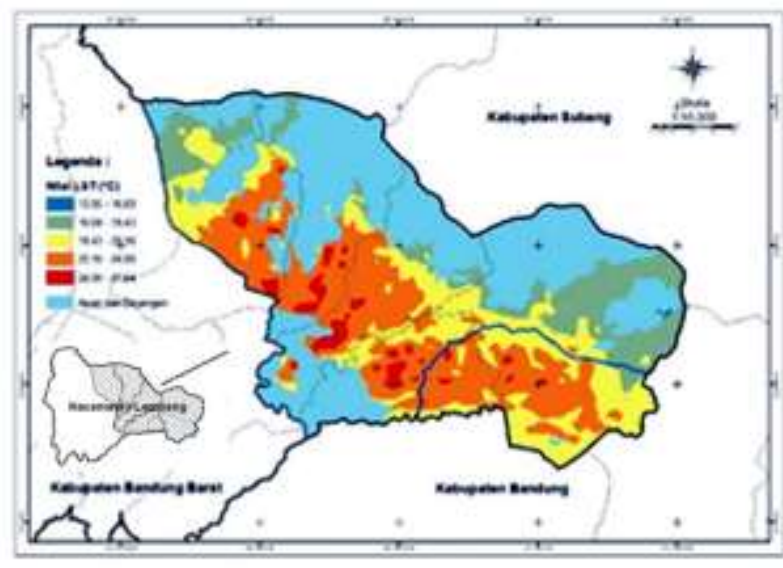

B

Gambar 3. Peta Persebaran Emisivitas (A) dan Sebaran LST (B) di Kecamatan Lembang. 
Emisivitas merupakan kemampuan objek untuk memancarkan energi yang dimilikinya dan berkaitan dengan proses absorpsi, pantulan dan transmisi dari suatu objek (Mallick et al., 2012). Emisivitas permukaan atau Land Surface Emmisivity (LSE) dipengaruhi tutupan lahan yang didapat melalui pendekatan vegetation indeks. Algoritma LSE membutuhkan nilai PV (Proportion of Vegetation) yang didapat dari nilai NDVI (Sobrino et al., 2008). Distribusi LST dipengaruhi oleh variasi indeks vegetasi (Sekertekin \& Bonafoni, 2020).

Pada lokasi studi, estimasi nilai LST berkisar $13,95{ }^{\circ} \mathrm{C}$ sampai $27,64{ }^{\circ} \mathrm{C}$ dan diklasifikasikan menjadi 5 kelas berdasarkan standar deviasinya (Tabel 5 dan Gambar 3Bb). Kelas LST 13,95 - 16,69 ${ }^{0} \mathrm{C}$ didominasi dengan tutupan awan, sehingga wilayah yang tertutup awan dalam penelitian ini tidak diperhitungkan dalam analisis. Tutupan awan akan mempengaruhi nilai LST yang sebenarnya, karena kandungan air yang tinggi akan membuat nilai LST semakin rendah pada area yang tertutup awan.

Berdasarkan nilai LST di lokasi studi, menunjukkan dominan nilai LST lebih dari $19,4{ }^{\circ} \mathrm{C}$. Ningrum \& Narulita (2018) mengungkapkan pada kisaran tahun 2005 hingga 2016 terjadi peningkatan suhu rerata $1,3{ }^{\circ} \mathrm{C}$ di Cekungan Bandung selaras dengan penurunan indeks vegetasi dan suhu di Bandung Utara dominan lebih dari $20{ }^{\circ} \mathrm{C}$. Peningkatan suhu yang terjadi dapat berpengaruh pada suhu udara di atasnya sehingga dapat meningkatkan evapotranspirasi di permukaan lahan dan kondisi kelembaban tanah menjadi lebih rendah. Kombinasi suhu permukaan yang meningkat dan kelembaban tanah yang menurun dapat memepengaruhi penurunan daya dukung kondisi tanah sebagai media tumbuh tanaman seperti pada pH (Karamina dkk., 2018) atau C organik (Hood, 2001).

Tabel 5. Luasan area berdasarkan kelas LST

\begin{tabular}{ccrr}
\hline \multirow{2}{*}{ No. } & Kelas LST & \multicolumn{2}{c}{ Luas } \\
\cline { 3 - 4 }$\left({ }^{0} \mathrm{C}\right)$ & $\left(\mathrm{km}^{2}\right)$ & \multicolumn{1}{c}{$\%$} \\
\hline 1. & $13,95-16,69$ & 2,45 & 0,09 \\
2. & $16,69-19,43$ & 5,78 & 21,05 \\
3. & $19,43-22,16$ & 9,09 & 33,11 \\
4. & $22,16-24,90$ & 11,53 & 42,01 \\
5. & $24,90-27,64$ & 1,03 & 3,73 \\
\hline
\end{tabular}

\section{Karakteristik Penggunaan Lahan Berdasarkan Nilai LST dan NDVI}

Lahan pertanian di Kecamatan Lembang didominasi tegalan/ladang dengan komoditas utama hortikultura. Tanaman hortikultura termasuk tanaman semusim, memiliki tinggi tanaman yang dominan rendah, dan jarak tanam yang kurang rapat sehingga terdapat tanah terbuka diantara tanaman. Karaktersitik tutupan lahan demikian akan menghasilkan nilai NDVI yang termasuk ke dalam kelas kehijauan rendah sampai sangat rendah.

Persebaran NDVI dan LST di lokasi studi berkaitan dengan variasi penggunaan lahan (Gambar 4). Nilai NDVI tinggi dan LST rendah cenderung terdapat pada lahan dengan tutupan vegetasi yang rapat. Sementara itu, nilai NDVI lebih rendah dan LST lebih tinggi terdapat pada lahan dengan tutupan vegetasi lebih rendah. Penggunaan lahan tegalan/ladang memiliki nilai LST dengan range $19,43-24,90^{\circ} \mathrm{C}$ namun dominan pada kelas range $22,16-24,90^{\circ} \mathrm{C}$, sedangkan pada penggunaan lahan perkebunan/kebun dan hutan memiliki nilai LST masing-masing pada kelas range $19,43-22,16^{\circ} \mathrm{C}$ dan $16,69-19,43^{\circ} \mathrm{C}$.

Nilai variasi NDVI juga dapat tergambarkan dengan nilai standar deviasi pada berbagai tutupan lahan. Pada Tabel 6 terlihat nilai standar deviasi NDVI tertinggi pada perkebunan/kebun $(0,113)$ dan terendah pada lahan terbangun $(0,058)$. Kecamatan Lembang memiliki jenis perkebunan yang beragam seperti kebun kopi, teh, karet, cengkeh, lada, dan kakao. Bentuk tajuk tanaman dan jarak tanam yang berbeda pada setiap jenis kebun dapat mempengaruhi variasi pantulan gelombang inframerah sehingga variasi nilai NDVI tinggi. Sementara lahan terbangun dan permukiman memiliki variasi nilai NDVI rendah yang disebabkan oleh persebaran vegetasi yang sedikit dan pantulan band SWIR yang lebih dominan dibandingkan NIR sehingga radiasi inframerah yang dipantulkan kecil dan nilai NDVI relatif lebih rendah. Hal ini selaras dengan Gamon et al. (1995) yang mengungkapkan bahwa NDVI dipengaruhi oleh karakteristik tanaman dan lingkungan.

Nilai LST pada hutan dan perkebunan/kebun lebih rendah dibandingkan dengan tegalan/ladang karena jenis vegetasi, bentuk daun, dan kerapatan tajuk pada kedua jenis guna lahan tersebut berbeda. Pada hutan dan perkebunan/kebun, kerapatan tajuk tanaman cenderung lebih rapat dibandingkan pada tegalan/ladang sehingga kandungan uap air yang lebih banyak pada hutan dan perkebunan/kebun 
dapat menyebabkan nilai LST yang lebih rendah daripada nilai LST pada tegalan/ladang.

Lahan terbangun atau permukiman dan lahan tanpa vegetasi memiliki nilai NDVI yang termasuk pada kelas kehijauan sangat rendah, sedangkan nilai LST ada pada range $24,90-27,64^{\circ} \mathrm{C}$. Hal ini disebabkan oleh sebaran vegetasi yang sedikit dan emisivitas pada material bangunan lebih rendah dibandingkan dengan vegetasi. Energi panas dari matahari dapat diserap dengan baik oleh material bangunan sehingga permukaan bangunan menjadi lebih cepat panas. Sensor TIRS merekam radiasi inframerah dari objek seperti lahan terbangun atau permukiman sehingga dapat mengdeteksi suhu permukaannya lebih tinggi dibandingkan objek lainnya yang tutupan vegetasinya lebih tinggi (Guha et al., 2018).
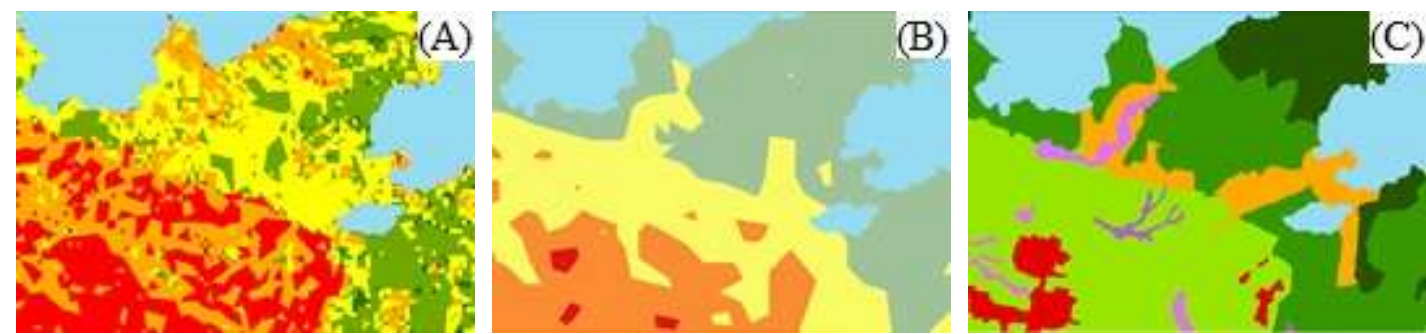

Gambar 4. Keragaman Penggunaan Lahan di Lokasi Studi Berdasarkan sebaran nilai NDVI (A) dan LST (B) pada berbagai Jenis guna lahan $(\mathrm{C})$. Keterangan:
$(\mathrm{A})=$ Kehijauan tinggi,
Kehijauan sangat rendah,
Kehijauan sedang,
Kehijauan rendah,
$(\mathrm{B})=\quad 13,95-16,69^{\circ} \mathrm{C}$, Lahan tidak bervegetasi
$24,90-27,64^{\circ} \mathrm{C}$
(C) = Hutan, $\quad$ Perkebunan/kebun, Tegalan/ladang, Sawah, Sawah tadah hujan, Semak belukar, Tanah terbuka, Lahan terbangun dan permukiman

Tabel 6. Karakteristik LST dan NDVI terhadap penggunaan lahan

\begin{tabular}{lrcccc} 
No. $\quad$ Penggunaan lahan & $\begin{array}{r}\text { Jumlah } \\
\text { piksel }\end{array}$ & $\begin{array}{c}\text { Rata-rata LST } \\
\left({ }^{\circ} \mathrm{C}\right)\end{array}$ & $\begin{array}{c}\text { Standar deviasi } \\
\text { LST }\end{array}$ & $\begin{array}{c}\text { Rata-rata } \\
\text { NDVI }\end{array}$ & $\begin{array}{c}\text { Standar deviasi } \\
\text { NDVI }\end{array}$ \\
\hline 1. Kawasan Hutan & 3.391 & 18,64 & 0,744 & 0,21 & 0,106 \\
2. Perkebunan & 7.063 & 19,88 & 1,054 & 0,17 & 0,113 \\
3. Tegalan/Ladang & 12.943 & 22,80 & 1,095 & $-0,01$ & 0,096 \\
4. Sawah (irigasi) & 790 & 22,54 & 1,209 & 0,01 & 0,101 \\
5. Sawah (Tadah Hujan) & 919 & 22,62 & 0,740 & 0,02 & 0,084 \\
6. Semak dan Belukar & 2.337 & 20,76 & 1,238 & 0,15 & 0,105 \\
7. Tanah Kosong & 54 & 23,71 & 0,471 & $-0,10$ & 0,066 \\
8. Lahan Terbangun & 2.882 & 24,30 & 0,844 & $-0,14$ & 0,058 \\
\hline
\end{tabular}

Nilai standar deviasi dapat menunjukan tingkat keragaman LST terhadap berbagai penggunaan lahan. Standar deviasi LST tertinggi terdapat pada semak belukar $(1,238)$. Tingkat keragaman vegetasi pada semak belukar sangat tinggi. Hal ini menyebabkan nilai LST yang bervariasi. Semak belukar ditumbuhi vegetasi yang heterogen dengan tingkat kerapatan jarang hingga rapat dan didominasi dengan vegetasi rendah seperti perdu (BSN, 2010). Sementara itu, nilai standar deviasi LST terendah terdapat pada tanah terbuka $(0,471)$, rendahnya keragaman objek pada permukaan tanah terbuka menyebabkan refleksi gelombang inframerah termal kecil dan seragam sehingga nilai LST lebih homogen.

Keragaan nilai indeks vegetasi dan LST di lokasi studi didominasi penggunaan lahan dengan tutupan lahan kerapatan rendah hingga tanpa vegetasi dan LST dominan lebih dari $19,4^{\circ} \mathrm{C}$. Keragaman vegetasi di lokasi studi cenderung kurang optimal bagi hulu sub DAS Cikapundung dalam menunjang fungsi ekologis DAS terutama dalam menangkap dan menyimpan air hujan di hulu DAS serta mengurangi erosi dan aliran permukaan. 
Selain itu juga vegetasi berperan menyangga suhu permukaan agar tidak panas. Peningkatan tutupan lahan melalui reboisasi di kawasan hutan, serta penerapan konservasi tanah-air yang tepat di area perkebunan dan tegalan atau ladang dapat meningkatkan kemampuan menangkap, menahan dan meresapakan air di Hulu Sub DAS Cikapundung.

\section{SIMPULAN}

Terdapat keragaman Indeks vegetasi dan LST di Hulu Sub DAS Cikapundung. Pada lokasi studi dominan memiliki nilai indeks vegetasi rendah hingga sangat rendah dan nilai LST lebih dari $19,4^{\circ} \mathrm{C}$ dan terdapat pada penggunaan lahan tegalan, lahan terbuka dan lahan terbangun. Keragaman penggunaan lahan di lokasi studi kurang optimal menunjang fungsi ekologis hulu sub DAS Cikapundung.

\section{DAFTAR PUSTAKA}

Arie, FC. 2012. Sebaran temperatur permukaan lahan dan faktor-faktor yang mempengaruhinya di Kota Malang. Prosiding Seminar Nasional Aplikasi Teknologi Prasarana Wilayah (ATPW). Surabaya. 11 Juli 2012.

Arista, CD, IS Widimulya, K Rahma, dan Mulyadi. 2017. Analisis vegetasi tumbuhan menggunakan metode transek garis (line transect) di kawasan hutan lindung Lueng Angen Desa Iboih Kecamatan Sukakarya Kota Sabang. Prosiding Seminar Nasional Biotik 2017. Pendidikan Sains Islami dalam Konteks Pengaplikasian Etnobiologi untuk Mewujudkan Generasi Berkarakter (SME Susilowati, Karman, Y Vitner, DAJ Selano, F Yacob, Mursito SB, R Koneri, C Roini, dan Mudatsir, Ed.). Hlm. 147-152.

[BSN] Badan Standarisasi Nasional. 2010. Klasifikasi Penutup Lahan. Jakarta.

Fawzi, NI. 2014. Pemetaan emisivitas permukaan menggunakan indeks vegetasi. Majalah Ilmiah Globe. 16(2): 133-139.

Feng, Y, C Gao, X Tong, S Chen, Z Lei, and J Wang. 2019. Spatial patterns of land surface temperature and their influencing factor: A case study in Suzhou, China. Remote Sensing. 11 (182).
Frananda, H, Hartono, dan RH Jatmiko. 2015. Komparasi indeks vegetasi untuk estimasi stok karbon hutan mangrove kawasan Segoro Anak pada kawasan Taman Nasional Alas Purwo Banyuwangi, Jawa Timur. Majalah Ilmiah Globe. 17(2):113-123.

Gamon, JA, CB Field, ML Goulden, KL Griffin, AE Hartley, G Joel, J Peñuelas, and R Valentini. 1995. Relationships between NDVI, canopy structure, and photosynthesis in three Californian vegetation types. Ecological Applications. 5(1):28-41.

Guha, S, H Gofil, A Dey, and N Gill. 2018. Analytical study of land surface temperature with NDVI and NDBI using Landsat 8 OLI and TIRS data in Florence and Naples city, Italy. European Journal of Remote Sensing. 51(1): 667-678.

Hidayati, IN, R Suharyadi, dan P Danoedoro. 2018. Kombinasi Indeks Citra untuk Analisis Lahan Terbangun dan Vegetasi Perkotaan. Majalah Geografi Indonesia. 32(1): 24-32.

Hood, RC. 2001. The effect of soil temperature and moisture on organic matter decomposition and plant growth. Isotopes in Environmental and Health Studies. 37(1): 25-41.

Irawan, S, dan J Sirait. 2017. Perubahan kerapatan vegetasi menggunakan citra Landsat 8 di kota Batam berbasis web. Jurnal Kelautan. 10(2): 174-183.

Jaya, INS. 2010. Analisis Citra Digital: Perspektif Penginderaan Jauh Untuk Pengelolaan Sumberdaya Alam. Fakultas Kehutanan IPB. Bogor.

Jiménez-Muñoz, JC, and JA Sobrino. 2003. A generalized single-channel method for retrieving land surface temperature from remote sensing data. Journal of Geophysical Research: Atmospheres. 108(D22). 4688, doi:10.1029/2003JD003480.

Karamina, H, W Fikrinda, dan AT Murti. 2017. Kompleksitas pengaruh temperatur dan kelembaban tanah terhadap nilai $\mathrm{pH}$ tanah di perkebunan jambu biji varietas kristal (Psidium guajava L.) Bumiaji, Kota Batu. Jurnal Kultivasi. 16(3): 430-434.

Kimuku, CW, and M Ngigi. 2017. Study of urban heat island trends to aid in urban planning in Nakuru Ccountry-Kenya. Journal of Geographic Information System. 9: 309-325. 
Kinthada, NR, MK Gurram, A Eadara, and VR Velagala. 2014. Land use/land cover and ndvi analysis for monitoring the health of micro-watershades of Sarada river basin, Vinsakhapatnam District, India. Journal of Geology \& Geosciences. 3(2): 1-7.

Kurniawan, S, WO Nurhaidar, dan I Salihin. 2017. Optimalisasi transformasi spektral UI, NDBI, NDVI dan Kombinasi Transformasi Spektral UI-NDVI dan NDBI-NDVI guna mendeteksi kepadatan lahan terbangun di Kota Magelang. Jurnal Geografi Aplikasi dan Teknologi. 1(1): 13-21.

Latif, MS. 2014. Land Surface Temperature Retrival of Landsat-8 Data Using Split Window Algorithm- A Case Study of Ranchi District. International Journal of Engineering Development and Research (IJEDR) Vol 2 (4): 3840-3848

Latuamury, B, T Gunawan, dan S Suprayogi. 2012. Pengaruh kerapatan vegetasi penutup lahan terhadap karakteristik resesi hidrograf pada beberapa SubDAS di Provinsi Jawa Tengah dan Provinsi DIY. Majalah Geografi Indonesia. 26(2): 99-116.

Lintang, NC, TB Sanjoto, dan H Tjahjono. 2017. Kajian kerapatan vegetasi hutan lindung Gunung Unggaran Jawa Tengah tahun 2016 menggunakan metode indeks vegetasi. Geo Image. (1): 1-6.

Mallick, J, CK Singh, S Shashtri, A Rahman, and S Mukherjee. 2012. Land surface emissivity retrieval based on moisture index from LANDSAT TM satellite data over heterogeneous surfaces of Delhi city. International Journal of Applied Earth Observation and Geoinformation. 19(1): 348-358.

Munawwaroh, A. 2016. Penerapan analisis vegetasi di hutan Mbeji daerah Wonosalam Jombang. Jurnal Pedagogia. 5(1): 103-110.

Ningrum, W, dan I Narulita. 2018. Deteksi perubahan suhu permukaan menggunakan data satelit Landsat Multi-Waktu (studi kasus Cekungan Bandung). Jurnal Teknologi Lingkungan. 19(2): 145-153.

Nurrochman, E. 2018. Kajian sistem hidrologi akibat perubahan tataguna lahan di kawasan Bandung Utara (Studi Kasus Kabupaten Bandung Barat). EnviroSan. 1(1): 26-28.

Peraturan Menteri Kehutanan Nomor P.12/MenhutII/2012. Perubahan Kedua Atas Peraturan
Menteri Kehutanan Nomor: P12 Tahun 2010 tentang Tata Cara Penyusunan Rencana Teknik Rehabilitasi Hutan dan Lahan Daerah Aliran Sungai (RTk RHLDAS).

Pertiwi, AD, NFA Safitri, dan DA Azahro. 2019. Penyebaran vegetasi semak, herba, dan pohon dengan metode kuadrat di Taman Pancasila. Proceeding of Biology Education. 3(1): 185-191.

Qin, Z, and A Karnieli. 2001. A Mono-window algorithm for retrieving land surface temperature from Landsat TM data and its application to the Israel-Egypt border region. International Journal of Remote Sensing. 22(18): 3719-3746.

Rismana, GA, dan Firmansyah. 2011. Evaluasi pemanfaatan ruang berdasarkan indeks konservasi di Sub DAS Cikapundung Hulu Provinsi Jawa Barat. Jurnal Lingkungan dan Bencana Geologi. 2(1): 49-66,

Salim, AG, IWS Dharmawan, dan BH Narendra. 2019. Pengaruh perubahan luas tutupan lahan hutan terhadap karakteristik hidrologi Das Citarum Hulu. Jurnal Ilmu Lingkungan. 17(2): 333-340,

Sandholt, I, K Rasmussen, and J Andersen. 2002. A Simple Interpretation of the surface temperature/vegetation index space for assessment of surface moisture status. Remote Sensing of Environment. 79: 213224.

Sekertekin, A, and S Bonafoni. 2020. Land ssurface temperature retrieval from Landsat 5, 7, and 8 over rural areas: assessment of different retrieval algorithm $\mathrm{ms}$ and emissivity models and toolbox implementation. Remote Sensing MDPI. 12(294): 1-17.

Soewarno. 1995. Aplikasi Metode Statistik untuk Analisa Data. Nova. Bandung.

Sobrino, JA, JC Jiménez-Muñoz, and L Paolini. 2008. Land surface emissivity retrieval from different VNIR and TIR Sensors. IEEE Transactions on Geoscience and Remote Sensing. 46(2): 316-325.

Sudiana, D dan E Diasmara. 2008. Analisis indeks vegetasi menggunakan data satelit NOAA/AVHRR dan TERRA/AQUAMODIS. Prosiding Seminar on Intelligent Technology and Its Applications. Hlm. 423428. 
Tucker, CJ. 1979. Red and Photographic Infrared Linear Combination fot Monitoring Vegetation. Remote Sensing of Environment. 8: 127-150.

Utomo, AW, A Suprayogi, dan B Sasmito. 2017. Analisis hubungan variasi land surface temperature dengan kelas tutupan lahan menggunakan data citra satelit Landsat (studi kasus: Kabupaten Pati). Jurnal Geodesi Undip. 6(2): 71-79.

USGS. 2019. Landsat 8 (L8) Data User Handbook. US Geological Survey. United State of America. South Dakota.
Valor, E, and V Caselles. 1996. Mapping land surface emissivity from NDVI: Application to European, African, and South American areas. ELSEVIER Remote Sensing of Environment. 57: 167-184.

Zhao, L, P Zhang, X Ma, and Z Pan. 2017. Land cover information extraction based on daily NDVI time series and multiclassifier combination. Hindawi. Vol. 2017, Article ID 6824051, 13 p. 